\title{
Islamic Thought in The Context of Socio-Cultural in The Short Story Cahaya Pelita Nurani
}

Normaizatul Anis Ahmad, Halis Azhan Mohd Hanafiah \& Kamariah Kamarudin

To Link this Article: http://dx.doi.org/10.6007/IJARBSS/v11-i19/12084

DOI:10.6007/IJARBSS/v11-i19/12084

Received: 29 August 2021, Revised: 20 September 2021, Accepted: 30 September 2021

Published Online: 11 October 2021

In-Text Citation: (Ahmad et al., 2021)

To Cite this Article: Ahmad, N. A., Hanafiah, H. A. M., \& Kamarudin, K. (2021). Islamic Thought in The Context of Socio-Cultural in The Short Story Cahaya Pelita Nurani. International Journal of Academic Research in Business and Social Sciences, 11(19), 441-454.

\section{Copyright: @ 2021 The Author(s)}

Published by Human Resource Management Academic Research Society (www.hrmars.com)

This article is published under the Creative Commons Attribution (CC BY 4.0) license. Anyone may reproduce, distribute, translate and create derivative works of this article (for both commercial and non-commercial purposes), subject to full attribution to the original publication and authors. The full terms of this license may be seen at: http://creativecommons.org/licences/by/4.0/legalcode 


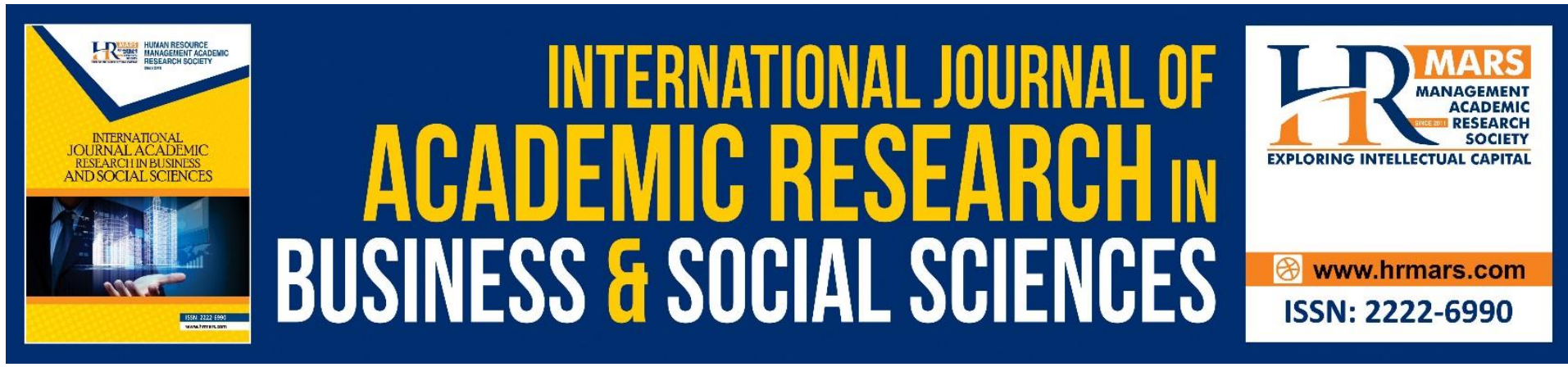

\title{
Islamic Thought in The Context of Socio-Cultural in The Short Story Cahaya Pelita Nurani
}

\author{
Normaizatul Anis Ahmad', Halis Azhan Mohd Hanafiah ${ }^{1,2,3}$ \& \\ Kamariah Kamarudin ${ }^{1}$ \\ ${ }^{1}$ Institute for Social Science Studies, Putra Infoport, Universiti Putra Malaysia, 43400 \\ Serdang, Selangor Darul Ehsan, ${ }^{2}$ Department of Malay Language, Faculty of Modern \\ Language and Communication, Universiti Putra Malaysia, 43400 Serdang, Selangor Darul \\ Ehsan. \\ Email: halis_azhan@upm.edu.my
}

\begin{abstract}
This article analyzes the Islamic thought in the context of socio-cultural of the community in the selected short stories. The focus of this study is (i) to classify the Islamic thought in the context of socio-cultural and (ii) to analyze the Islamic thought in the context of socio-cultural in order to identify its relation with community in eight selected stories based on the relevance of the aspect studied. Short story Cahaya Pelita Nurani (2015) by Nazri Hussein will be used for this discussion which related to community approach. This approach saw the arts as a tool for exposure questions that arise and seeks to find the good and wellbeing of society as required by Islam. Besides that, the methods involved are library research and content analysis. The results of this study found that the Islamic thought in the context of sociocultural of the community based on the eight selected stories touches the question of beliefs, education, attitude and outlook on life also Malay heritage in accordance with the community approach.
\end{abstract}

Keywords: Islamic Thought, Socio-Culturals, Community Approach, Community, Short Story Cahaya Pelita Nurani.

\section{Introduction}

According to (Osman, 1988), socio-cultural is a study related to the culture and society which includes politics, culture, family, religion, changes and development of the Malay community. According to (Kadir, 2000), the value in the life of the Malays is based on the Quran and the Hadith. He added that the Islamic features have been the basis towards behaviour and action, forms of relationship, the essence of values and attitudes as well as the view of socio-cultural systems of the Malays. Therefore, based on the statement, it can be understood that Islam is a comprehensive religion because it contains a complete and comprehensive rules of life in all aspects of people's life, including the cultural aspects.

Accordingly, this paper focuses on the aspects of Islamic thought in the socio-cultural context discussed in selected short stories in the Cahaya Pelita Nurani collection of short stories. This collection of short stories presents a number of Malays characters who practice 
Islam teachings in their lives. Eight stories were identified highlighting Islamic thought in the socio-cultural context namely "Aku Belum Mati Lagi", "Keranda Untuk Bonda", "Makna Dalam Warna", "Penjara Cinta", "Pelita Nurani", "Fitrah", "Lelaki dan Sebuah Gua" and "Jentayu Mengepak Langit". All of these stories are seen to be in line with the aspects studied. Based on the discussion of previous studies, it is found that these studies focus on the aspects of Islamic thought, values and Islamic themes. Based on what has been conducted, it is found that no specific study of Islamic thought in a socio-cultural context has been conducted in the Cahaya Pelita Nurani collection of short stories.

\section{Highlights of Past Studies}

According to (Zain, 1991), thought becomes the base or pulse that animates the spirit of a writer to widen the path of struggle through works of art. Writers and creators often talk about society and humanity in their work. Besides, (Zain, 2000) added, humanity means concern for the fate of human beings, which aims to eradicate poverty, oppression, and provide freedom, justice and happiness requires the widest possible struggle. Therefore, without thoughts and ideas, a work and writing will not be successfully produced. Thus, a lot of discussion about the thoughts were triggered in the Malay literature works.

Some literature research that touches on the aspects of thought has been done by (Isin, 2003) entitled "Cerpen Melayu Mutakhir: Analisis Pemikiran dan Teknik Naratif", which focuses on the development of Malay short stories from the 1970s to the 1990s. The study found that in those three decades, the short story genre grew rapidly. This is detected in terms of the issues that have become the thoughts of the author and the narrative techniques applied to develop a short story. Among other factors are the authors, publishing institutions, financial institutions, institutions of higher education, readers and literary organizations. The study also concludes that there are three thoughts, themes and issues expressed dominantly in the Malay short stories during the period, which is the thought of socio-economic, sociopolitical as well as leadership.

Next, (Mat, 1999) in "Pemikiran dalam Puisi-Puisi Penyair Lepasan Maktab Perguruan Sultan Idris Selepas Merdeka" studied the poem collection Tulisan di Kamar Tidur (1960) authored by Suhaimi Hj. Muhammad, Timbang Terima (1970) authored by Kemala, Penemuan (1975) authored by A. Wahab Ali, Wawa Maya (1974) authored by Dharmawijaya and Kesan Kunjungan (Traces of a journey) (1982) authored by Rahman Shaari. He found that the aspects of thinking are related to the aspects of community. The aspects of community that are focused on are the social, economic, political and religious aspects. The study was made to clarify the poet's self-introspection with the elements of community life by using a sociological approach. The results found a strong relationship between the poet's self-introspection and family. Secondly, the relationship of the poet's self-introspection with the rural and urban communities. Finally, there is also the relationship of the poet's self-introspection with the political situation and religious beliefs in the society.

Next, (Ahmad, 2000) in "Sajak-sajak Masuri S.N: Analisis Pemikiran dan Bentuk Luaran" discusses the aspects of thought and external forms of the poems of Masuri S.N. from year 1945 to 1995 . The poems are divided into two eras, namely the era before independence and the era after independence. In the aspect of thought, there are four main aspects, namely nationalism, community, self-introspection, and thought about nature. Meanwhile, the aspect of thought of Masuri S.N.'s poems after independence (1957-1995) discussed are related to aspects of politics and nationalism, love of homeland and national dignity, politics and morals of politicians, community, poverty, moral values of community, community 
relations, reform and modernization, and self-introspection. The thought of self-introspection is divided into poetry, religion and divinity, as well as the meaning of life. A stylistic approach is used in analyzing these aspects. The results showed that not only that there was a change in the external form of the poem but a dominant change also occurred in the aspect of thinking between the poem before and after independence.

Next, a study by (Mohamad, 1997) entitled "Penerapan Nilai-Nilai Islam dalam NovelNovel Pilihan Shahnon Ahmad" found that the idea of Islamic thoughts and ideologies which was misunderstood by the Malays has become a practice in their lives. In addition, there are also calls on the need for Malays to progress in any field.

In addition, (Salleh, 1998) in his writing about "Cermin Diri: Esei-esei Kesusasteraan" talks about thinking and its relationship with the state of a community, how to deal with its environment and also the determinants of its connection. This study found that thinking is able to test the power of the mind and its race. A strong nation is said to be a nation that can answer the larger questions such as man's relationship with God, man with nature and man with man.

Next, (Isin, 2003) in his writing about "Pengalaman Memperkasakan Visi dan Pemikiran Puisi-Puisi Baha Zain" examines the poems of Baha Zain collected in Esei dan Puisi Baha Zain (DBP, 2000: 91-157) namely "Turki", "Petaling Jaya", "Kuala Lumpur", "lowa City", "Chicago", "Ann Arbor", "Paris", "Jordan", "Cairo", "Jakarta”, and "Madrid". The focus of the study is on aspects of thought, form and speech style. Among the aspects of thinking and vision found are those related to socio-economics and socio-politics.

Next, (Abdullah, 1996) in "Pengislaman Kesusasteraan: Beberapa Pandangan Sarjana Islam" found that the Islamization of literature can be done if the writer himself is able to improve the creed and Islamic thoughts. This is because only true, straight and solid Islamic thought is capable of producing tasawwuf (Sufism) literary works on divinity, life, nature and man in the spirit of Islam.

All in all, it is found that there have been studies related to Islamic thought done by previous researchers who studied in various genres of arts. However, Islamic thought in a socio-cultural context is not specifically looked on. Thus, studies that touch on the aspects of Islamic thought in a more comprehensive socio-cultural context should be done. Furthermore, the aspects of Islamic thought in the socio-cultural context in the Cahaya Pelita Nurani collection of short stories have yet to be studied. Therefore, this discussion is expected to meet the main question that is the focus of the study that is related to Islamic thought in the context of socio-cultural in the selected material.

\section{Community Approach}

In line with the research on the aspects of the "Islamic thought" and "socio-cultural", this paper applies the Community Approach in the Malay Methodology Theory by Hashim Awang in year 1994. The Malay Methodology Theory presented is based on all aspects of human life such as the way, attitudes, beliefs and local culture of the Malay community (Mat, 2013). According to (Awang, 2002), the formation of a work is based on the reality of life and religion of the author. The Malay Methodology Theory is divided into two methodologies namely Natural Methodology and Religious Methodology. Both of these methodologies are related to one and another.

Firstly, Natural methodology is based on the lifestyle or attitude of the Malay community that put nature as part of themselves. This aspect can reflect the thoughts of the Malays. This theory was outlines with the notion that art is part of the nature object which 
means that an artwork is produced based on observation and from the creator's life experience (Awang, 2002). These nature objects include animals, plants, and humans. The Natural Method is divided into three approaches, namely the Applied Approach, the Moral Approach and the Premonition Approach. Secondly, (Awang, 2002) stated that Religious Methodology is based on faith that is united to the beliefs of Islam. This method is derived from the Qur'an and Hadith which serve to highlight the nature of the majesty of Allah to and enhance taqwa. This Religious Methodology is divided into three approaches, namely the Da'wah Approach, the Community Approach, and the Art Approach.

This article used the Community Approach in achieving the objectives outlined. Through this approach, art is considered as a tool of exposure for the questions that arise in the life of the community and seeks to find goodness and justice based on Islamic understanding. This study used content analysis of selected short stories in the Cahaya Pelita Nurani collection of short stories to look at the question of beliefs, education, attitude and outlook on life, and Malay heritage. These questions will be seen the ways and attitudes of life that are practiced in community's life from the Islamic point of view using the Community Approach. This study highlights the phenomenon of community life on good moral values to strengthen the relationship with other people and their environment with the Islamic values in the short stories. According to (Awang, 2002), the Community Approach is able to assess the problems of society in the work and the author through the idea of writing that is highlighted in the work. He added that the Community Approach aims to seek the wellbeing of life and the strengthening of human faith in Allah s.w.t. As such, these questions are appropriately applied with the Community Approach to analyze the Islamic thought in a sociocultural context in the eight selected stories.

\section{Research Objective}

This study outlines two objectives as follows:

i. To classify the Islamic thought in the context of socio-cultural in the Cahaya Pelita Nurani collection of short stories.

ii. To analyze the Islamic thought in the context of socio-cultural in the Cahaya Pelita Nurani collection of short stories in order to identify its relation with community.

\section{Findings and Discussion}

Analysis of the Cahaya Pelita Nurani collection of short stories using the Community Approach found that Islamic thought in the context of socio-cultural raised several questions that are related which are beliefs, education, attitude and outlook on life and Malay heritage as shown in Table 1 below.

Table 1: Islamic Thought in Socio-cultural Context

\begin{tabular}{ccc}
\hline & & Sosio-cultural \\
\hline No & Question & Title of the Short Story \\
\hline 1. & Beliefs & "Lelaki Dan Sebuah Gua", "Aku Belum Mati Lagi" \\
2. & Education & "Fitrah", "Pelita Nurani", "Penjara Cinta" \\
3. & Attitude \& Outlook on & "Makna Dalam Warna", "Pelita Nurani", \\
& Life & "Keranda Untuk Bonda" \\
4. & Malay Heritage & "Jentayu Mengepak Langit", "Keranda Untuk Bonda" \\
\hline
\end{tabular}


Based on Table 1 above, it is found that there are eight stories that carry Islamic thought from a socio-cultural aspect, namely "Lelaki Dan Sebuah Gua", "Aku Belum Mati Lagi", "Fitrah", "Pelita Nurani", "Penjara Cinta", "Keranda Untuk Bonda", "Makna Dalam Warna", and "Jentayu Mengepak Langit".

\section{Beliefs}

According to (Katan, 2004) describes "belief" as; "Belief are mental concepts, theoretical constructs, held to be true or valid, and are formed in response to perceived needs. They provide the idealized examples (for instance of conduct) for the frames, and as such provide us with expectations about what the world should be like". Based on the statement by Katan, belief is something that is considered true. Beliefs also serve as a framework or guide in life. Beliefs tend to be a limiting factor rather than a justifying factor. The concept of belief given by Katan focuses on belief from the point of view of religion. In this study, what is said to be a belief is a belief in Islam itself. This is so because Islam serves as the way of life of human beings who believe in Allah s.w.t.

\section{Belief in Religion}

According to (Marekan \& Seong, 2013), religion supports human life by acting as a way of life. Belief is an appreciation in human beings. Usually, belief is born of clear understanding and high awareness. Through a passage in the short story "Lelaki dan Sebuah Gua", through the character Emmanual displays about his belief in religion which can be seen in the passage below;

"...The mind is God. To reject the logic of reason means to reject the truth itself.

That's his grip for a long time. It is a permanent hold and will not change forever."

(Hussein, 2015: 15)

Based on the passage above, Emmanual's character is told not to believe in religion. For him religion is a thing created by man himself. In fact, Emmanual's character is told to believe that the mind is his God. In the short story "Lelaki dan Sebuah Gua", Emmanual's character is presented as an archaeologist serving at the United States International Geological Center in Manhattan. Therefore, the character Emmanual understands that the universe is created by itself and does not involve the power of God. From this passage, it is clear that from the deeds of the character Emmanual shows his belief is merely on the mind alone. However, his belief began to change to a belief in Islam and Allah s.w.t. after getting to know Ahmad Nuruddin who is a newspaper reporter of Wadah Melayu. This statement can be seen as in the following passage;

"...For your information, I am in the process of performing umrah in Baitullah (House of God). This cave has radiated the light of guidance to me."

(Hussein, 2015: 22)

Based on the quotation from the letter of the character Emmanual to Ahmad Nuruddin above, it shows that the belief of the character Emmanual has changed from worshiping the mind to believing in the religion sent by Allah s.w.t. This is evidenced by the actions of the character Emmanual who reverted to Islam after he studied the Cave of Hira which was suggested by Ahmad Nuruddin. Indirectly, the old Emmanual character beliefs have turned to the belief of Islam. After getting to know Ahmad Nuruddin, Emmanual's 
character has started to believe in Allah and decided to revert to Islam. Emmanual was performing umrah at the time the letter was sent. Here, it is clearly seen that beliefs can be changed in the presence of good motivating factors by changing superstitious beliefs to true ones.

Next, the belief in religion can also be seen in the short story "Aku Belum Mati Lagi". This belief is seen in the character of a cruel Jewish leader who has killed many innocent lives of people. For example in the following passage;

Ah, I don't want to die yet! No! Give me a little time to regret and repent of the injustice I have done before. Don't kill me first, God. Don't. Don't do it yet. I'm not ready yet. Argh, I've seen that light! ...

(Hussein, 2015: 105)

Based on this passage, the Jewish leader is told in the end he repented and wished he had been given a chance to live. This is because the Jewish leader has received a just retribution as a result of his cruel deeds. The Jewish leader had fallen ill and became the subject of experiments in the hospital by selected specialist doctors. The character of the Jewish leader finally accepted Islam at the end of his life. Although at first the Jewish leader committed atrocities by killing Muslims in Palestine, yet by the time the Jewish leader was about to die he had expressed his repentance to Allah s.w.t. This clearly shows that the beliefs of the Jewish leader have changed from Western beliefs to beliefs in Islam.

Thus, based on the example of the passage, it can be understood that the change in religious beliefs of the character of Emmanuel and the character of the Jewish leader is a picture of a person who changed his belief in Allah because at first they did not have faith in Allah and Islam. However, later they began to believe in Islam. This coincides with the community approach that emphasizes the elements of goodness and Islamic law (Awang, 2002). Through this approach, the question of faith is as a question rooted in the purpose of goodness and well-being to society as demanded in Islam.

\section{Education}

According to (Affendi, 2016), some literary works contain thoughts related to education. In fact, formal and informal education are interrelated with each other. According to her, the formal education system also has informal education. Thus, education is a system in life that includes various activities to shape one's personality. Education in Islam is sourced from the Quran and Hadith where the source of education is based on Islamic beliefs. Education in Islam covers all aspects of life in this world and also in the hereafter. In this study, the education discussed is education based on the Quran, education based on the stories of the prophets and education from parents. Education aims to develop human knowledge, skills, spirituality and physicality.

\section{Education from the Quran}

According to (Stapa et. al, 2012), in the context of Islamic education, education should be based on the Quran and Sunnah which is based on tauhid (monotheism) and the oneness of Allah s.w.t. Failure to place the Quran and Sunnah in Islamic education will result in failure in forming a Muslim personality that is committed to the demands of the religion. The Quran is an absolute source to be referred to as a guide of life. There is a lot of knowledge to be gained from it that covers all aspects of human life. The Qur'an and hadith are sources sent directly 
from Allah s.w.t to mankind. The short story "Fitrah" highlights the importance of Islamic education based on the Quran. An example can be seen in the following passage;

“...We believe in the truth of God's revelation. Al-Quran which gathers sirah and stories that started from Prophet Adam AS...."

(Hussein, 2015: 92)

Based on the passage, the short story "Fitrah" is told that the Qur'an plays a role as the main source in providing education to human beings. This passage tells how the contradiction of religious beliefs brought by a character who is a Western ideology that plays a role in inciting the character Mas to drift in the Western ideology which is contrary to the teachings of Islam. It is narrated that the character Mas was incited to dress as a woman, commit acts that are contrary to Islam and change his gender to a woman. However, Mas finally realizes that what has accompanied him all this time are things that is against his nature as a Muslim. The character Mas says that he as a servant of Allah believes in the truth of the Qur'an. The character Mas aware that he had almost committed an act that is contrary to Islam. Because Mas had an education from the Quran, he then escaped from the perverse teachings. It is clear here that education from the Qur'an is very important in order to maintain one's faith.

\section{Education from the Stories of the Prophets}

According to (Stapa et. al., 2012), education in Islam has a very high and important position and it becomes an inseparable entity with Islam because it is a demand and an obligation. For example, Rasulullah s.a.w strongly encouraged the Muslim community to deepen their knowledge. Education also occurs from the stories of the prophets which tell a lot about the challenges of the prophets in defending Islam. Education from the story of the prophet is displayed in the short story "Penjara Cinta" which is highlighted through the character of Syahrul Hakimi. Example is in passage as follows;

...Isn't this gift also once possessed by Prophet Yusuf once upon a time? The great man snapped his fingers as a sign of gratitude when he was ordered to be locked up in prison for the sake of dignity. He was once familiar with the head. History that was recorded in the pages of God's word.

(Hussein, 2015: 25)

Based on the passage above, this short story "Penjara Cinta", presents the character of a man named Syahrul Hakimi who has served as an educator in a private primary school in Stockholm has been imprisoned for caning a student named Nicholas Olsson. Under the Western education act, the act of caning students even for the purpose of educating is wrong. This is in contrast to the Islamic education which enables the act of caning to educate students for the reason not to injure but to educate. While in prison, Syahrul Hakimi said that he believed that there was rationale in being given the test by taking lessons from the story of Prophet Yusuf. From this passage, it is clear that the character of Syahrul Hakimi took a lesson from the story of Prophet Yusuf a.s which gave him the strength to go through the test.

\section{Education from Parents}

According to (Stapa et. al., 2012) who quoted a hadith narrated by Imam al-Bukhari and Abu Hurairah r.a, Rasulullah s.a.w said (Bukhari t.th. 5), the importance of parental education is revealed in a hadith as follows: 
No child is born except on Al-Fitra (Islam) and then his parents make him Jewish, Christian or Magian.

Based on the hadith quotation above, (Stapa et. al., 2012) explains the passage of the hadith which means that parents play a very important role in the early education such as forming the foundations of a child's self-development. Parents are the closest people to their children. Therefore, parents play an important role in educating their children with a perfect upbringing in line with the teachings of Islam and shaping a noble personality of children. The role of education from these parents can be seen in the short story "Pelita Nurani" as in the following passage;

... The advice of our parents every time night falls: "As you illuminate the night with the light of a lamp, also illuminate the house of the soul with the light of true character and faith.

(Hussein, 2015: 2)

From this passage, education with elements of advice can be traced in the short story "Pelita Nurani" when the children's characters are told to tell about their parents' advice on the importance of maintaining character and faith. The advice had a profound effect on the psyche of the children's characters. This passage shows that parents play a role in educating their children to be true Muslim. In this short story "Pelita Nurani", the character of the parents always reminds their children to take good care of their faith. This is further supported by a passage in the same story;

... Therefore, our elders educated the generation to liven up the dawn with the duha prayer so that the blessings of the day are opened with an abundance of sustenance and goodness.

(Hussein, 2015: 4)

In this passage it can be seen that parents should always provide informal education to their children. Parents always remind their children to practice duha prayers every morning so that Allah s.w.t. will grant sustenance and goodness into their lives. The character of parents plays an important role in shaping the personality of their children. Children are constantly reminded to draw closer to Allah s.w.t. and stay away from forbidden things. It is clear here that education from parents is very important to produce children with noble personalities as required in Islam.

Based on the question of education that is through the Quran, the stories of the prophets and parents, it can be seen that these questions are appropriate and in accordance with the community approach. This is because, according to (Awang, 2002), a perfect and prosperous community can be achieved when they believe in the existence and power of Allah s.w.t. Through this approach, the question of education is a question that is rooted in the purpose of goodness and well-being to the community as demanded in Islam.

\section{Attitude and Outlook on Life}

According to (Nur'aini, 2020), every Muslim is encouraged to implement the teachings of Islam comprehensively in all aspects of his life because Islam does not only revolve around worship but also all aspects of human life. When the whole of life has been on the joints of the teachings of Islam, then will be born the true happiness that is the purpose of life of every human being. Therefore, attitude and outlook on life is an important thing. This is because, if 
a person does not have a view of life, then his life seems to have no direction. In addition, according to (Wahyudi, 2017), the meaning and purpose of life, the determination of moral values, views on life should be based on the teachings of Islam as a guideline and standard of life for every Muslim. Therefore, this study looks at attitudes and views of life from the aspects of tauhid, khalifah (successor) and justice.

\section{Tauhid}

According to (Nasir et. al, 2019), Sunnah explains that Allah s.w.t created human beings in hanifiyah (belief in Allah) and provided them with the holy instincts that guide them to deify Allah s.w.t. A human being has tauhid by acknowledging the oneness of Allah s.w.t. as the creator of the universe. The principle of tauhid is the basis of faith in which the recognition of the oneness of Allah s.w.t. as god. There is no god but Allah s.w.t. not even there is one like Him. Attitudes and outlook on life based on monotheism must be present in every Muslim. The display of tauhid can be seen in the short story "Makna Dalam Warna" through the character of Ahmad Habib as in the following passage;

... According to Ahmad Habib, the system and values of life must be based on the principles of faith that worship the Almighty.

(Hussein, 2015: 56)

This passage shows that the character of Ahmad Habib is an artist who is involved in the field of painting. From the passage, the character Ahmad Habib explains to Irfan about his painting which uses the image of a tree by equating it with tauhid. In this story, Ahmad Habib explains the meaning of his painting. According to Ahmad Habib's explanation, the lush tree is equated with human faith. Human's life needs to have a solid foundation so as not to be easily deceived by external elements. The oneness of Allah s.w.t. needs to be acknowledged in order to have a life of faith. From the explanation of Ahmad Habib's character, it is clear that Ahmad Habib's character fulfills the attitude of a Muslim. The character of Ahmad Habib explains how important it is for human beings to have the principle of tauhid that is able to lead them to a life that is pleasing to Allah s.w.t.

\section{Khalifah}

According to (llyas, 2016) who quoted the Ensiklopedia Islam, in the concept of Islam, man is the khalifah that is as a representative, successor or ambassador of God on earth. With his position as the khalifah of Allah s.w.t on earth, man is given responsibilities and how he performs the sacred duties of his caliphate. Therefore, in carrying out that responsibility, human beings are equipped with various potentials such as the mind that gives the ability for human beings to do so. Khalifah are generally defined as rulers on earth. Someone who has power and rules according to what Allah s.w.t. order, will surely be a good khalifah. The characters of the parents in the short story "Pelita Nurani" show about their role as the khalifah of the family. This can be seen as shown in the following passage;

... The advice of our parents every time night falls: "As you illuminate the night with the light of a lamp, also illuminate the house of the soul with the light of true character and faith.

(Hussein, 2015: 2)

The passage above shows the character of parents who always give useful advice related to Islam to their children in order to maintain their faith. Parents plays role as khalifah and 
always remind their children that their souls and character should be enlightened with true faith. Children need to be constantly given useful guidance and advice because they cannot understand it on their own. The passage of the story above shows that parents carry out their responsibilities well and strive to educate their children with the teachings of Islam.

Moreover with the next passage;

... When we were young, our hearing lobes just heard the words, but we are not able to understand and appreciate every word and talk that is full of philosophy.

(Hussein, 2015: 3)

From this passage, the nature of a khalifah in the parents has given religious education to children since childhood. This is so because the above passage shows that at first the character of the children was still small and did not understand the meaning of their parents' advice. Although they could not understand the meaning of their parents' advice, the parents tried to be a good khalifah over their children. In this short story, parents always give advice and words of encouragement so that children do not forget the religion and always adhere to the teachings of Islam. Therefore, the role of the khalifah in the family is indeed important to educate children to become a Muslim with a noble personality.

\section{Justice}

According to (Dail \& Zabidi, 2009), teachings of Islam indeed uphold the principle of justice in the implementation of the Divine law. The Qur'an records the command to implement justice in all activities in the world. The third principle in the Islamic view of life is justice. Justice is a concept of attitudes that can be seen in human treatment. Fairness is indeed important in all things. In the short story "Keranda Untuk Bonda", justice can be seen through the passage below;

... Her voice kept buzzing in our hearing lobes: "Bonda is not fair. Bonda is picky. Bonda practices discrimination. Bonda distinguishes each offspring. Bonda tore apart the love of children with unequal attention and upbringing. Bonda over-indulges some of her grandchildren with undeserved gifts and rewards. Bonda is biased...."

(Hussein, 2015: 75)

The quote above shows the anger of a son who feels that his mother is not being fair to him. The man had acted to scold his mother. From the man's actions, it is seen that a fair attitude should be inculcated in the family because the son of the character Bonda has felt that his mother is not being fair to the children. The son's character has rebelled and scolded his mother in front of the other siblings. Bonda's character is said to be biased and does not give the same education and attention. From this passage, it is clear that justice is indeed important in Islam because injustice will ravage a family institution in lead to a family that is pleasing to Allah s.w.t.

Thus, based on the question of attitudes and outlook on life on tauhid, khalifah and justice is coincident with the societal approach that emphasizes on believing in the existence and power of Allah s.w.t to achieve the perfection of life (Awang, 2002). Therefore, mankind who obeyed all of God's commands and stayed away from His prohibitions will achieve a peaceful life. 


\section{Malay Heritage}

According to (Sahad et. al, 2013), heritage and customs of the Malays has been proven through many writings that the Malay community have absolutely thick and strong beliefs and customs in doing things. Behind the heritage of traditional games, indigenous dances, living cultural practices and so on have elements of thought and beliefs that overshadow them. The thoughts and beliefs of this customary heritage are passed down from one generation to the next since time immemorial beginning with the beliefs of animism, dynamism, Hindu-Buddhism and finally the teachings of Islam. Holding these beliefs have shaped Malay customs, including the slaves in the past, to the palace. However, for the Malays, Islam views dominant in everything and behavioral practical life. The question of Malay heritage is highlighted in the short story "Jentayu Mengepak Langit". An example can be seen in the following passage;

... The words of the mother who often instructed every time she learned to reach the sky and the rainbow: "Fly with the strength of soul and integrity of conscience...

(Hussein, 2015: 69)

... At that moment, he seemed to hear a noble message from his mother who stepped into the ribs of his conscience: "Do not give up, Jentayu..."

(Hussein, 2015: 72)

Based on this passage, it is said that the Malay heritage must be maintained as best as possible. It was also mentioned about the symbol of the character Jentayu that does not give up with Geroda who wants to spoil the Malay heritage. Jentayu is actually the analogy of "Malay heritage" while Geroda refers to "development". From this passage, the message to be conveyed is Malay heritage must be protected and cannot be destroyed due to the construction. Additionally, it is also told that the mother character reminds that in order to maintain the Malay heritage, the soul must be intact with religious knowledge. Indirectly, this passage shows a link between heritage and religion. Thus, it can be seen that the importance of preserving the religion and heritage of the ancestors.

Next, in the short story "Keranda Untuk Bonda" also highlighted the Malay heritage. In this story, the 57 years old Bonda character is maintaining the Malay heritage. Examples can be seen in the passage;

... It is observed Bonda wears a traditional dress and an elegant hijab that perfects the manners and morals of the ancestral heritage...

(Hussein, 2015: 79)

Based on the above passage, the character Bonda shows that she really takes care of the Malay heritage that is considered as the identity of the Malays. Bonda is 57 years old and still preserves the legacy. The novel place the character Bonda as someone who always wear baju kurung, the symbol of manner and moral of Malays dan cover her aurat as demanded in Islam. Because of this, the neighbors also praised Bonda. From the character Bonda, it is clear that the Malay heritage must be maintained as best as possible and should be handed down from generation to generation as an inheritance Malay heritage of ancestors. In addition, the short story "Keranda Untuk Bonda" shows Malay heritage that is related to games. This can be seen in the passage below; 
... Some girls choose to play congkak and batu seremban because the game does not require much physical energy...

(Hussein, 2015: 77)

Based on the above passage, the Malay heritage is also seen in the game that has been a tradition since the era of ancestors. In the passage, the game of congkak and batu seremban is a hereditary game from previous generations. Islam also linked with the Malay heritage because heritage is a game that does not involve the social interaction. This is because, from the passage it is understood that the game of congkak and batu seremban is often played by girls only. There is no mixing between women and men. Thus, it can be seen the role of religion in limiting association in the game.

Thus, in accordance with the community approach, examples of these short story passages raise the role of religion and the Malay heritage that seem to be in line with community approach. This is in line with the views of (Awang, 2002) whom stated that the community approach see the life of the Malays with Islam as a guide of life that does not allow them to be passive or to withdraw from the question of its people.

\section{Conclusion}

Based on the questions posed in the socio-cultural aspect, it is clear that Islamic thought is presented through the short stories contained in the Cahaya Pelita Nurani collection of short stories namely in the short stories "Aku Belum Mati Lagi", "Keranda Untuk Bonda", "Makna Dalam Warna", "Penjara Cinta", "Lelaki dan Sebuah Gua", "Fitrah", "Pelita Nurani" and "Jentayu Mengepak Langit" with some questions which are belief, education, attitude and outlook on life, and Malay heritage which in turn indicates the welfare and wellbeing. The questions raised are also intended to see how Islamic thought in a socio-cultural context can be linked to community life in the selected short stories. The analysis used the Community Approach in the Malay Methodology Theory by Hashim Awang. The issues found involve the aspects of community that lead to goodness and progress that can affect life as demanded by Islam. Based on the analysis of the material studied, it can be concluded that Islamic thought is identified and classified through the questions raised in socio-cultural aspects. Next, this study achieves the second objective which is to analyze Islamic thought in a socio-cultural context and finally be able to relate it to community life in the short stories.

\section{Reference}

Abdullah, S. N. A. S. (1996). Pengislaman Kesusasteraan: Beberapa Pandangan Sarjana Islam. Dewan Sastera. September 1996: 22-31.

Affendi, N. R. N. M. (2016). Ekspresi Psikologi dalam Novel Pilihan. Kuala Terengganu: Penerbit UMT Universiti Malaysia Terengganu.

Ahmad, S. (2000). Sajak-sajak Masuri S.N.: Analisis Pemikiran dan Bentuk Luaran. Tesis Sarjana. Universiti Putra Malaysia.

Awang, H. (2002). Teori Perkaedahan Melayu dan Prinsip Penerapannya. Kertas Kerja dalam Bengkel Kajian Teori Sastera Melayu, anjuran Bahagian Teori dan Kritikan Sastera Dewan Bahasa dan Pustaka. Melaka: Riviera Bay Resort 28-29 Jun 2002.

Dail, M. Z. M., \& Zabidi, T. (2009). Petunjuk-Petunjuk Keadilan Sosial. Jurnal Penyelidikan Islam. Volume 22. 2009: 117-138. 
Dewan Redaksi Ensiklopedi Islam. (2003). Ensiklopedi Islam Jilid 3, Jakarta, PT Ichtiar Baru van Hoeve dlm Rahmat Ilyas. 2016. "Manusia Sebagai Khalifah dalam Perspektif Islam". Mawa izh, Vol. 1 No. 7 Jun 2003: 169-195.

Hussein, N. (2015). Kumpulan Cerpen Cahaya Pelita Nurani. Kuala Lumpur: Institut Terjemahan dan Buku Malaysia.

Ilyas, R. (2016). Manusia Sebagai Khalifah dalam Perspektif Islam. Mawa izh, Vol. 1 No. 7 Jun 2016: 169-195.

Isin, R. S. (2003). Pengalaman Memperkasakan Visi dan Pemikiran Puisi-Puisi Baha Zain dalam Monograf Bahasa, Sastera, dan Budaya Melayu. Jabatan Bahasa Melayu. Fakulti Bahasa Moden dan Komunikasi. Universiti Putra Malaysia. 8, 113-115.

Isin, R. (2003). Cerpen Melayu Mutakhir: Analisis Pemikiran dan Teknik Naratif dalam Monograf Bahasa, Sastera, dan Budaya Melayu.. Jabatan Bahasa Melayu. Fakulti Bahasa Moden dan Komunikasi. Universiti Putra Malaysia. 8, 107-129

Kadir, W. A. (2000). Tradisi dan Perubahan Norma dan Nilai Di Kalangan Orang-Orang Melayu. Kuala Lumpur: Masfami Enterprise.

Katan, D. (2004). Translating Cultures: An Introduction for Translators, Interpreters and Mediators. Manchester: St. Jerome Publishing.

Mat, N. (2013). Pemikiran Dharmawijaya Menterjemahkan Sosialisasi Masyarakat Desa dan Kota. Perak: Penerbitan Universiti Pendidikan Sultan Idris.

Mat, N. (1999). Pemikiran dalam Puisi-puisi penyair lepasan Maktab Perguruan Sultan Idris Selepas Merdeka. Tesis Sarjana. Universiti Putra Malaysia.

Marekan, N. H. A., \& Seong, G. S. (2013). Strategi Penterjemahan Nilai dan Kepercayaan dalam Novel Sungai Mengalir Lesu. Jurnal Bahasa. Vol 13. No. 2. 2013: 273-291.

Mohamad, N. (1997). Penerapan Nilai-Nilai Islam dalam Novel-Novel Pilihan Shahnon Ahmad. Tesis Sarjana. Jabatan Melayu. Universiti Kebangsaan Malaysia.

Nasir, K., Rahim K. Z., \& Mamat, S. (2019). Kepercayaan Terawal Manusia Menurut Sunnah: Analisis Terhadap Buku Teks Sejarah Tingkatan Satu Terbitan Kementerian Pendidikan Malaysia. Journal Hadis Vol. 9 No. 17 2019: 30-47.

Nur'aini, A. (2020). Islam Sebagai Pandangan Hidup (Studi Pemikiran Hamka Dalam Buku Falsafah Hidup). Skripsi. Jurusan Pendidikan Agama Islam Fakultas Tarbiyah dan Ilmu Keguruan Institut Agama Islam Negeri Ponorogo, Pembimbing Hawwin Muzzaki, M.Pd.I.

Osman, M. T. (1988). Kebudayaan Melayu dalam Beberapa Persoalan. Kuala Lumpur: Dewan Bahasa dan Pustaka.

Salleh, M. H. (1998). Cermin Diri: Esei-Esei Kesusasteraan. Petaling Jaya: Penerbit Fajar Bakti Sdn. Bhd.

Sahad, M. N., Abdullah, A. H., \& Abdullah, S. (2013). Syarak Mengata Adat Memakai: Tinjauan Terhadap Adat Warisan Melayu Perlis dari Perspektif Akidah dan Teori 'uruf Syarak. Jurnal Antarabangsa Dunia Melayu. Volume 6. No. 1. 2013: 34-58.

Stapa, Z., Yusuf, N., \& Shaharudin, A. F. (2012). Pendidikan Menurut Al-Quran dan Sunnah Serta Peranannya Dalam Memperkasakan Tamadun Ummah. Jurnal Hadhari Special Edition 2012: 7-22.

Wahyudi, T. (2017). Peranan Pendidikan Islam Dalam Membangun World View Muslim Di Tengah Arus Globalisasi. Cendekia Vol. 15 No. 2, Julai-Disember 2017: 319-340.

Zain, B. (1991). Penyair, Puisi, dan Kemanusiaan. Dewan Sastera 21: 1 Januari 1991: 18-21.

Zain, B. (2000). Esei dan Puisi: Tentang Penulis dan Persekitarannya. Kuala Lumpur: Pustaka Cipta Sdn. Bhd. 